\title{
Three new species of subfamily Politzariellinae (Lepidoptera: Cossidae) from Guinea and Zambia
}

\author{
Три новых вида подсемейства Politzariellinae \\ (Lepidoptera: Cossidae) из Гвинеи и Замбии
}

\author{
R.V. Yakovlev ${ }^{1,2}$, G.C. Müller, ${ }^{3,4}$, V.D. Kravchenko', \\ G. Petrányi ${ }^{6}$, Sz. Sáfián ${ }^{7}$ \\ Р.В. Яковлев ${ }^{1,2}$, Г.К. Мюлмер ${ }^{3,4}$, В.А. Кравченко \\ Г. Петрани ${ }^{6}$ Ж. Сафиан ${ }^{7}$
}

\footnotetext{
${ }^{1}$ Altai State University, Lenina pr. 61, RF-656049 Barnaul, Russia.

${ }^{2}$ Tomsk State University, Laboratory of Biodiversity and Ecology, Lenina pr. 36, 634050 Tomsk, Russia. E-mail: yakovlev_asu@mail.ru

${ }^{3}$ Department of Parasitology, Kuvin Center for the Study of Infectious and Tropical Diseases, The Hebrew University — Hadassah Medical School, Jerusalem, Israel. E-mail: guntercmuller@hotmail.com

${ }^{4}$ Faculty of Medicine, Pharmacy and Odontostomatology, Malaria Research and Training Center, University of Sciences, Technique and Technology of Bamako, Mali.

${ }^{5}$ Department of Zoology, George S. Wise Faculty of Life Sciences, Tel Aviv University, Tel Aviv 69978, Israel. E-mail: vasiliy@post.tau.ac.il

${ }^{6}$ Zoologische Staatssammlung München, Münchhausenstraße 21, 81247 München, Germany. E-mail: pertu.g@gmail.com

${ }^{7}$ African Natural History Research Trust, Leominster, Street Court Kingsland, Herefordshire, HR6 9QA, G.B. E-mail: szsafian@gmail.com

${ }^{1}$ Алтайский государственный университет, пр. Ленина 61, Барнаул 656049, Россия.

${ }^{2}$ Томский государственный университет, Лаборатория биоразнообразия и экологии, пр. Ленина 33, Томск 634050, Poccия. E-mail: yakovlev_asu@mail.ru
}

KEY WORDS: Cossidae, Carpenter moths, fauna, taxonomy, new species, Africa, Guinea, Zambia.

КЛЮЧЕВЫЕ СЛОВА: Cossidae, древоточцы, фауна, таксономия, новые виды, Африка, Гвинея, Замбия.

ABSTRACT. The article provides an illustrated description of three new species, Holcoceroides cheick Yakovlev, Müller, Kravchenko et Petrany, sp.n. (type locality — Guinea Konakri, Macenta Prefecture, Ziama Forest), Politzariella edita Yakovlev, Müller, Kravchenko et Petrany, sp.n. (type locality - Guinea Konakri, Macenta Prefecture, Ziama Forest, Mt. Nimba), Politzariella frici Yakovlev et Sáfián, sp.n. (type locality - Zambia, Mwinilunga district, North-Western Province, Chiwoma riverine forest).

РЕЗЮМЕ. Приведено иллюстрированное описание трёх новых видов: Holcoceroides cheick Yakovlev, Müller, Kravchenko et Petrany, sp.n. (type locality - Guinea Konakri, Macenta Prefecture, Ziama Forest), Politzariella edita Yakovlev, Müller, Kravchenko et Petrany, sp.n. (type locality — Guinea Konakri, Macenta Prefecture, Ziama Forest, Mt. Nimba), Politzariella frici Yakovlev et Sáfián, sp.n. (type locality — Zambia, Mwinilunga district, NorthWestern Province, Chiwoma riverine forest).

\section{Introduction}

Cossidae (Lepidoptera) of Africa are still poorly studied. There are faunistic reviews only on individual countries: Malawi [Yakovlev, Murphy, 2013], Zimbabwe [Yakovlev, Lenz, 2013], Zambia [Yakovlev, 2014], the Republic of South Africa, Namibia [Mey, 2015, 2016], Swaziland [Yakovlev, Witt, 2016a], the Central African Republic [Yakovlev et al., 2018] and Burundi [Yakovlev, Witt, 2019].

The subfamily Politzariellinae Yakovlev, 2011 was established for two monotypic African genera Politzariella Yakovlev, 2011 (type species: Politzariella pantherina Yakovlev, 2011) and Holcoceroides Strand, [1913] (type species: Holcoceroides ferrugineotincta Strand, [1913]) [Yakovlev, 2011]. Later, new representatives of the subfamily were described from equatorial Africa: Geraldocossus Yakovlev et Sáfián, 2016 with type species (by monotypy) Geraldocossus durrelli Yakovlev et Sáfián, 2016 from Mount Cameroon and Politzariella fontainei Yakovlev et Witt, 2016 from Congo [Yakovlev, Sáfián, 2016; Yakovlev, Witt, 2016b].

How to cite this article: Yakovlev R.V., Müller G.C., Kravchenko V.D., Petrányi G., Sáfián Sz. 2019. Three new species of subfamily Politzariellinae (Lepidoptera: Cossidae) from Guinea and Zambia // Russian Entomol. J. Vol.28. No.3. P.312-316. doi: 10.15298/rusentj.28.3.10 
Examining the new materials collected in different African regions, we have discovered three new species. Their descriptions are given below.

\section{Material and methods}

The genitalia were mounted in Euparal on slides following Lafontaine [2004]. The photographs of collection specimens were taken by the digital camera of Apple iPhone 7 32GB, illuminated in Lightbox. The images were processed using CorelDraw software.

\section{Taxonomy part}

Holcoceroides cheick Yakovlev, Müller, Kravchenko et Petrany, sp.n.

Figs 1-2.

MATERIAL. Holotype: $\sigma^{7}$, Guinea Konakri, Macenta Prefecture, Ziama Forest, 550 m, Mt. Nimba, March 2017, leg. G. Petranyi, V.D. Kravchenko et G.C. Müller (coll. G. Müller, Freising / later Zoologische Staatssammlung, Munich, Germany; slide MüllerCossidae 2019/01-\#4); $4 \sigma^{\top} \sigma^{\top}, 1$, same locality and data (coll. G. Müller, Freising); 1 ', same locality and collectors, August 2016 (coll. G. Müller, Freising).

DESCRIPTION. Length of fore wing $15 \mathrm{~mm}$. Antenna belt-like, not pectinate. Thorax and abdomen densely covered with pale brown scales. Fore wing wide, apically rounded. Costal edge brown, with dusting of dark brown scales; marginal, submarginal and postdiscal areas dark brown, discal and basal areas brown, with dusting of dark brown scales, fringe dark brown, unicolorous. Hind wing grey, without pattern, fringe dark brown, unicolorous.

Male genitalia. Uncus split into two halves, with deep semicircular notch; gnathos arms short, ribbon-like; gnathos strongly sclerotized, consisting of two pyramidal halves fused basally; valve with smooth, almost parallel costal and abdominal edges, apically semicircular, robust harpe with serrated edge at costal edge of valve; transtilla with fine sharp prongs basally; transtilla processes short, leaf-like, slightly sharpened apically; juxta robust, of a very complicated shape: with two pairs of dorsally directed processes, medial processes long, thin, lateral processes twice shorter, cuneal, with thin sharp apices; saccus very long, apically semicircular; phallus thin, almost straight, vesica aperture in dorso-apical position, vesica without cornuti.

Female. Length of fore wing $17 \mathrm{~mm}$. Fore wing slightly wider and darker than that of male.

DIAGNOSIS. Externally, the new species is very similar to the type species of the genus, H. ferrugineotincta (type locality - Nkolentangan [Equatorial Guinea]), from which it significantly differs in the genital structure:

- the wide notch on the uncus (in H. ferrugineotincta, the notch on the uncus is narrow);

- the gnathos consisting of two pyramidal halves (in $H$. ferrugineotincta, the gnathos consists of two short flattened sclerites);

- the harpe shaped as process with serrated edge (in $H$. ferrugineotincta, the harpe is shaped as a double long hook); - the fundamentally different structure of the uncus.

The founding of a twin-species in the genus Holcoceroides, previously considered to be monotypic, necessitates the mandatory examination of the genitals of Holcoceroides sp. specimens for accurate material identification. The discovery of new species is quite possible.
COLLECTION SITE AND HABITAT DESCRIPTION (Fig. 7). The Guinean Montane Forest eco-region consists of scattered mountains and high plateau areas surrounded by the Guinean Savannah zone. Average rainfall is between 1,600 2,400 mm per year [Morton, 1972, 1986], and most major rivers in West Africa origin in this area.

The Ziama Massif, located in southern Guinea, is a part of this eco-region and extends south into Liberia as the Kpo Range. The Ziama Forest was designated a nature reserve in 1932 and approved as a Biosphere Reserve by UNESCO in 1980 , covering $1,161.70 \mathrm{~km}^{2}$. On the foothills and in the valleys, the common plant associations include Uapaca togoensis, Cola lateritia, Parinari excelsa, Piptadeniastrum africanum and Canarium schweinfurthii. The understory vegetation is dominated by Ochna membranacea, Caloncoba echinata and Morus mesozygia, together with a limited herbaceous layer. Both species were collected more than 10 years ago just outside the reserve near Seredou village [ $550 \mathrm{~m}$ a.s.1.]. Though there are still some patches of natural vegetation in this area, the local vegetation has considerably deteriorated during the last 10 years. The habitat pictures were taken along the road from Seredou village on the entrance of the reserve to Ballasou village.

On the Ziama Massif territory, the following endemic Lepidoptera species were indicated: Abantis fabiana Belcastro, 2015 (Hesperiidae), Junonia agnesberenyiae Sáfián, 2018 (Nymphalidae), Goodia praedicta Bouyer, 2009 (Saturniidae) [Bouyer, 2009; Belcastro, Oremans, 2015; Sáfián, 2018].

ETYMOLOGY. The new species is dedicated to Dr. Sekou Fantamady Traore (called by his friends "Cheick"), the Professor of Medical Entomology, director of the Malaria Research and Training Center (MRTC) and head of the Department of Medical Entomology and Vector-borne Diseases at the faculty of Medicine (University of Sciences, Techniques and Technologies of Bamako (USTTB), Mali).

\section{Politzariella edita Yakovlev, Müller, Kravchenko et Petrany, sp.n. \\ Figs 3-4.}

MATERIAL. Holotype: $\sigma^{7}$, Guinea Konakri, Macenta Prefecture, Ziama Forest, 550 m, Mt. Nimba, August 2016, leg. G. Petranyi, V.D. Kravchenko et G.C. Müller (coll. G. Müller, Freising / later Zoologische Staatssammlung, Munich, Germany; slide MüllerCossidae 2019/01-\#1)

DESCRIPTION. Length of fore wing $10 \mathrm{~mm}$. Antenna belt-like, not pectinate. Thorax and abdomen densely covered with dark brown scales. Fore wing brown, pattern poorly expressed. Thin dark brown line along costal edge, big round dark brown spot in postdiscal area, dark brown jagged spot in discal area (cubitally). Hind wing brown, without pattern. Fringe on all wings brown.

Male genitalia. Uncus forked, between two mastoid apices, with deep wide semicircular notch; gnathos arms short, thick, apices strongly sclerotized, tapered, edges slightly jagged; gnathos reduced; valve wide, with semicircular extension on costal edge, outer and abdominal edges smooth, small mastoid slightly sclerotized harpe on inner surface of valve (in medium third, close to costal edge); transtilla processes spinous, straight, thin, directed dorsally; juxta of complicated shape, cylindrical, robust, with long narrow tapered lateral processes, directed dorsally; saccus small, semicircular; phallus equal to valve in length, of medium thickness, slightly curved in medium third, vesica aperture in dorsoapical position, 1/4 of phallus in length, vesica without cornuti.

Female unknown. 
DIAGNOSIS. The new species reliably differs from the known species of the genus Politzariella pantherina Yakovlev, 2011 (type locality — Ober Volta [Burkina Faso], Bobo Dioulasso) and Politzariella fontainei Yakovlev et Witt, 2016 (type locality - [Congo] Uele, Paulis [Isiro], $\left.\left[2^{\circ} 462003 \mathrm{~N} / 27^{\circ} 372003 \mathrm{E}\right]\right)$ externally and in the male genital structure:

- the new species is the smallest in the genus, the fore wing length is $10 \mathrm{~mm}$ (in all the known species, $12-15 \mathrm{~mm}$ );

- big brown spots on the fore wing (in all the known species, the pattern is reticulated);
- wide semicircular process on the costal edge of the valve (in the other species of the genus, the process is sharper, with a smaller base);

- significantly thinner phallus (in all the known species, it is much thicker).

COLLECTION SITE AND HABITAT DESCRIPTION (Fig. 7). See the previous species description.

ETYMOLOGY. The new species is dedicated to Dr. Edita Revay, the Professor of Medical Sciences at the faculty of Medicine (University of Sciences, Techniques and Technologies of Bamako (USTTB), Mali).
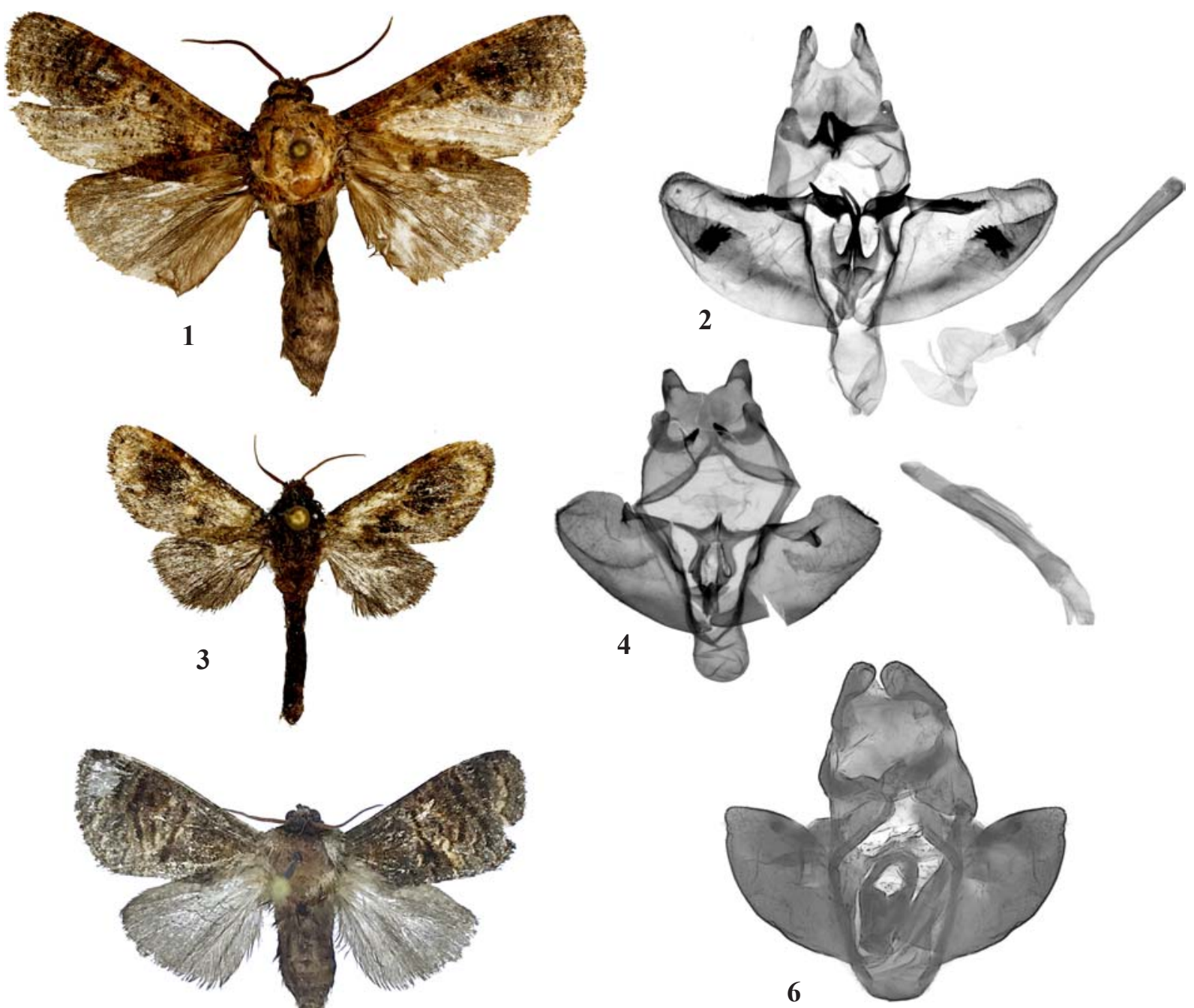

5

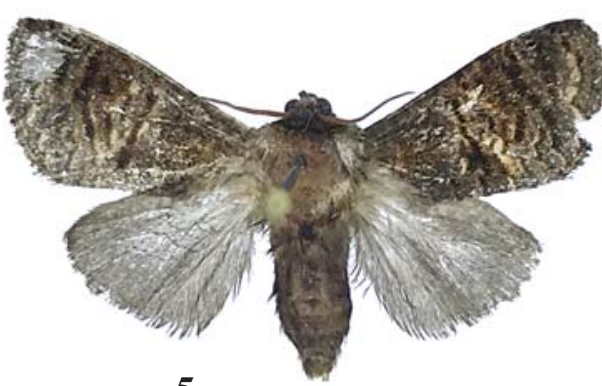

6

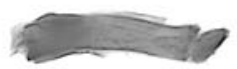

$10 \mathrm{~mm}$

لـســــا

$1 \mathrm{~mm}$

Figs 1-6. Politzariellinae, adult males and male genitalia: 1 - Holcoceroides cheick Yakovlev, Müller, Kravchenko et Petrany, sp.n., holotype; 2 - Holcoceroides cheick, male genitalia (holotype); 3 - Politzariella edita Yakovlev, Müller, Kravchenko et Petrany, sp.n., holotype; 4 - Politzariella edita, male genitalia (holotype); 5 - Politzariella frici Yakovlev et Sáfián, sp.n., holotype; 6 - Politzariella frici, male genitalia (holotype).

Рис. 1-6. Politzariellinae, самцы и гениталии самцов: 1 - Holcoceroides cheick Yakovlev, Müller, Kravchenko et Petrany, sp.n., голотип; 2 - Holcoceroides cheick, гениталии самца (голотип); 3 - Politzariella edita Yakovlev, Müller, Kravchenko et Petrany, sp.n., голотип; 4 - Politzariella edita, гениталии самца (голотип); 5 - Politzariella frici Yakovlev et Sáfián, sp.n., голотип; 6 — Politzariella frici, гениталии самца (голотип). 


\section{Politzariella frici Yakovlev et Sáfián, sp.n. Figs 5-6.}

MATERIAL. Holotype: $\bigcirc^{\Upsilon}$, Zambia, Mwinilunga district, NorthWestern Province, Chiwoma Forest 13.XI.2015 12²6'41.74'’S,

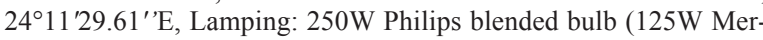
cury vapour $+125 \mathrm{~W}$ Wolfram), leg. Szabolcs Sáfián et Zdenek Faltynek Fric (Zoologische Staatssammlung, Munich, Germany; slide coll/Yakovlev 2019 \# 14).

DESCRIPTION. Length of fore wing $11 \mathrm{~mm}$. Antenna belt-like, not pectinate. Thorax and abdomen densely covered with dark brown scales. Fore wing wide, short, brown, with pattern of more or less expressed dark brown undulated lines, mostly expressed in discal and postdiscal areas. Hind wing grey, without pattern. Fringe on all wings grey, unicolorous.

Male genitalia. Uncus forked, with deep semicircular notch apically; gnathos arms short, thick; gnathos poorly structured, poorly sclerotized; valve leaf-like, with smooth edges, slightly tapered apically, small poorly sclerotized baglike harpe on inner surface of valve (in medium third, closer to costal edge); juxta robust, with two robust lateral processes, directed abdominally; saccus semicircular, of medium size; phallus thick, slightly shorter than valve, vesica aperture in dorso-apical position, vesica without cornuti.

Female unknown.

DIAGNOSIS. The new species is very different from the known species of the genus by a number of characters:

- the fore wing is shorter and wider than in the other species;

- the new species has gnathos (in the other species, it is reduced);

- the specific leaf-like valves with smooth costal edge (in the other species, there is an expressed semicircular process).

Possibly, the species belongs to a genus new to science, but currently we have only one specimen which does not allow to reliably determine the generic affiliation.

COLLECTION SITE AND HABITAT DESCRIPTION (Fig. 8). The habitat around Chiwoma is a typical Cryptosepalum forest, a unique, closed canopy dry forest type, which is distributed only on a small area on the high plateau in Eastern Angola and North-western Zambia (Lunga West), also as small patches in the nearby areas of the DRC. The main tree species of the forest type is Cryptosepalum exfoliatum, and the forest is characterized by a higher canopy layer (15-20 m), a lower canopy layer and an almost impenetrable shrub layer. Cryptosepalum forests are among the least studied forest habitats in Africa and are known to host a number of rainforest butterfly species [e.g. Teniorhinus ignita (Mabille, 1877) - Sáfián, unpublished] and Charaxes Ochseheimer, 1816 species endemic to this habitat type [Heath et al., 2004]. The species was collected at the beginning of the rainy season after a longer period of drought.

ETYMOLOGY. The new species is dedicated to Dr. Zdenek Faltynek Fric (Institute of Entomology ASCR, Department of Ecology and Conservation Biology, Èeské Budìjovice, Czech Republic) who collected this new species.

Thus, currently there are 7 known species in the Politzariellinae subfamily, belonging to three genera. The representatives of this subfamily are distributed in equatorial Africa (mostly in the West). It seems necessary to continue the study on the genus Holcoceroides in order to reveal the real boundaries of the species habitats, and possibly, to find twin species.

\section{References}

Belcastro C., Oremans Ph. 2015. Notes on the genus Abantis Hopffer, 1855 with description of two new species (Lepidoptera: Hesperiidae, Pyrginae) // Fragmenta Entomologica. Vol.48. P.5359

Bouyer T. 2009. Description de nouveaux Goodia Holland, 18933 (Lepidoptera, Saturniidae) // Entomologia Africana. Vol.14. No.1. P.21-27.

Heath A., Newport M.A., Hancock D. 2002. The Butterflies of Zambia. African Butterfly Research Institute, Nairobi, Kenya et The Lepidopterists' Society of Africa. 137 pp.

Lafontaine J.D. 2004. Noctuoidea, Noctuidae (part), Noctuinae (part-Agrotini) // R.W. Hodges (ed.). The Moths of America North of Mexico, fasc. 27.1. Washington: The Wedge Entomological Research Foundation. P.1-385.

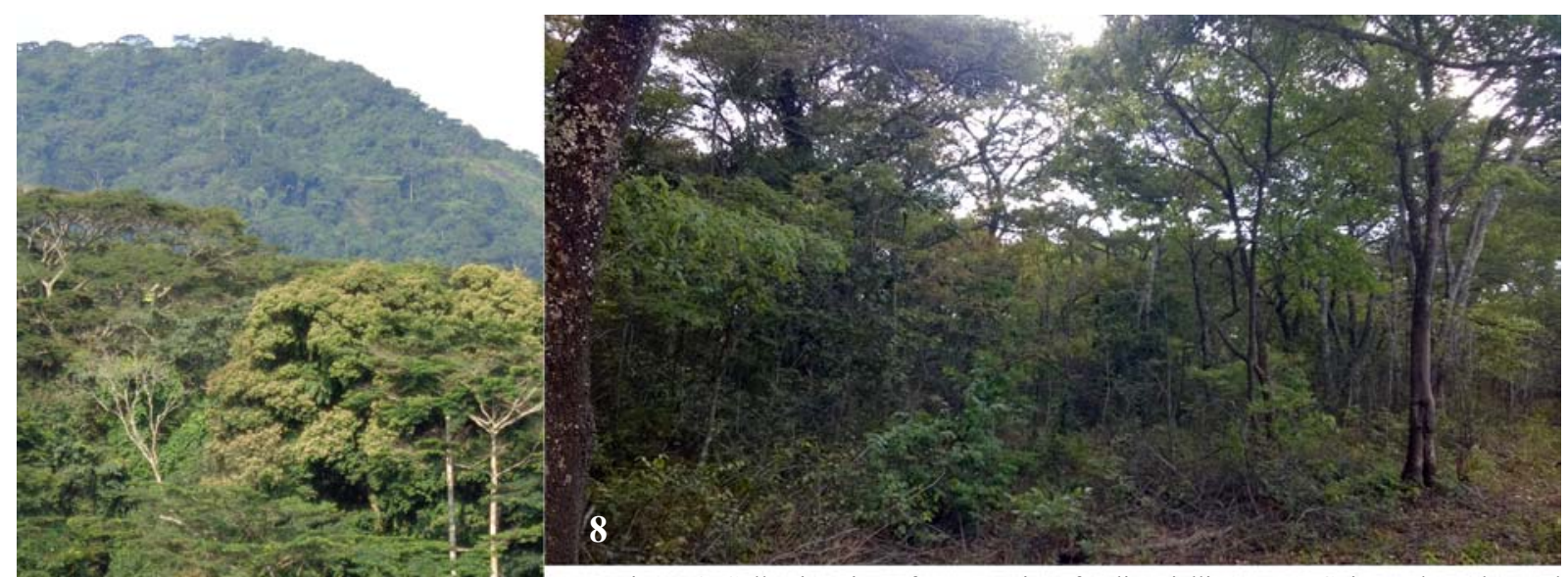

Figs 7-8. Collection sites of new species of Politzariellinae: 7 - Guinea, along the road from Seredou village to Ballasou village within the Ziama Forrest Reserve (photo by G. Müller); 8-Zambia, Mwinilunga district, North-Western Province, Chiwoma Forest (photo by Sz. Sáfián).

Рис. 7-8. Места сбора новых видов Politzariellinae: 7 - Гвинея, дорога от деревни Середоу до деревни Балласоу, лесной заповедник Зиама (фото Г. Мюллера); 8 Замбия, Северо-Западная провинция, район Мвинилунга, лес Чивома (фото Ж. Сафиана). 
Mey W. 2015. Revision of the genus Arctiocossus Felder, 1874 and allied genera (Lepidoptera: Cossidae: Cossinae) // Annals of the Ditsong National Museum of Natural History. Vol.5. P.28-55.

Mey W. 2016. A taxonomic and faunistic study of the Cossidae of southwestern Africa (Lepidoptera: Cossoidea) // Annals of the Ditsong National Museum of Natural History. Vol.6 P.146-198.

Morton J.K. 1972. Phytogeography of the West African mountains // D.H. Valentine (ed.). Taxonomy, Phytogeography and Evolution. London: Academic Press. P.221-236.

Morton J.K. 1986. Montane Vegetation // G.W. Lawson (Ed.). Plan Ecology in West Africa. United Kingdom: John Wiley and Sons Ltd. P.247-271.

Sáfián Sz. 2018. Junonia agnesberenyiae sp. nov. (Lepidoptera, Nymphalidae, Nymphalinae) from the Nimba Mountains (Guinea), West Africa // Metamorphosis. Vol.29. P.126-131.

Yakovlev R.V. 2011. Catalogue of the Family Cossidae of the Old World // Neue Entomologische Nachrichten. Bd.66. S.1-129.

Yakovlev R.V. 2014. Cossidae (Lepidoptera) of Zambia // Check List. Vol.10. No.4. P.724-728. DOI: 10.15560/10.4.724.
Yakovlev R.V., Laszlo G., Witt T.J. 2018. First data of Cossidae (Lepidoptera) of the Central African Republic // Ukrainian Journal of Ecology. Vol.8. No.4. P.379-382.

Yakovlev R.V., Lenz J. 2013. On the Fauna of Cossidae (Lepidoptera) of Zimbabwe with description of a new species // Zootaxa. Vol.3718. No.4. P.387-397. DOI: 10.11646/zootaxa.3718.4.8.

Yakovlev R.V., Murphy R.J. 2013. The Cossidae (Lepidoptera) of Malawi with descriptions of two new species//Zootaxa. Vol.3709. No.4. P.371-393. DOI: 10.11646/zootaxa.3709.4.5.

Yakovlev R.V., Sáfián Sz. 2016. Geraldocossus gen. nov. (Lepidoptera, Cossidae) from Mount Cameroon (West Africa) // Zootaxa. Vol.4114. No.5. P.595-599. DOI: 10.11646/zootaxa.4114.5.8.

Yakovlev R.V., Witt Th.J. 2016a. Carpenter-Moths (Lepidoptera: Cossidae) of Swaziland, South Africa // Far Eastern Entomologist. No.311. P.9-12.

Yakovlev R.V., Witt T.J. 2016b. Politzariella fontainei - new Cossidae (Lepidoptera) species from Congo // Biological Bulletin of Bogdan Chmelnitskiy Melitopol State Pedagogical University. Vol.6. No.3. P.154-156.

Yakovlev R.V., Witt Th.J. 2019. Cossidae (Lepidoptera) of Burundi (first results) // Ecologica Montenegrina. Vol.20. P.105-109. 